Article

\title{
Carbon Dioxide Emissions, Economic Growth, and Selected Types of Fossil Energy Consumption in China: Empirical Evidence from 1965 to 2015
}

\author{
Hongze Li, Bingkang $\mathrm{Li}^{*}$ and Hao Lu \\ School of Economy and Management, North China Electric Power University, Beijing 102206, China; \\ lihongze@ncepu.edu.cn (H.L.); luhao@163.com (H.L.) \\ * Correspondence: libingkang7@gmail.com \\ Academic Editors: Jeffrey Logan and Doug Arent \\ Received: 16 March 2017; Accepted: 20 April 2017; Published: 28 April 2017
}

\begin{abstract}
This paper empirically investigates the interactions among $\mathrm{CO}_{2}$ emissions, economic growth, and three selected types of fossil energy consumption (coal, gas, and oil) using time series data from China over the period 1965-2015. Classic econometric analysis technologies including the Johansen cointegration test, the vector error correction model (VECM), and the Granger causality test based on VECM are employed to meet our objectives, and the presence of breaks in the data is also considered. Cointegration test result supports the existence of a long-run equilibrium relationship among the five variables, and the error correction mechanisms of the system involving the five variables are proven to be effective by VECM. Additionally, the Granger causality test based on VECM reveals that the bidirectional causalities between GDP and coal consumption, between GDP and gas consumption, and between coal consumption and $\mathrm{CO}_{2}$ emissions and unidirectional causalities running from GDP and oil consumption to $\mathrm{CO}_{2}$ emissions, from GDP to oil consumption, and from coal consumption to oil and gas consumption are found. Furthermore, several policy implications are proposed in the final section of this paper based on the empirical results.
\end{abstract}

Keywords: carbon dioxide emissions; economic growth; selected types of fossil energy consumption; econometric analysis

\section{Introduction}

Energy is not only the cornerstone of economic development, but also an important strategic resource for a country. For China, in the stage of industrialization, it is self-evident that energy plays a major role today. The last several decades have witnessed great achievements in the economic development and rapid growth of energy consumption in China. For instance, China has become the largest energy consumer, with the proportion of the world's total energy consumption attributed to China having grown from $3.53 \%$ to $23.40 \%$ during the period $1965-2015$.

However, the excessive energy consumption has brought dramatic increases in $\mathrm{CO}_{2}$ emissions. In 2015, the total amount of $\mathrm{CO}_{2}$ emissions in China reached 9.7611 billion tons, which was nearly 20 times that the emissions in 1965. With the further increases in the rate of global warming, it has become a mandatory requirement for China's economic development to control $\mathrm{CO}_{2}$ emissions. Meanwhile, China is gradually entering a new economic normality with a moderate or slow economic growth rate rather than the past rapid one, indicating that changing the past energy-dependent development mode is pressing.

Over the past several decades, the international community has attached great importance to carbon emissions and signed a number of related agreements, such as the Kyoto Protocol in 1997, which aimed to stabilize greenhouse gas levels in the atmosphere at an appropriate level, and the Copenhagen 
Accord in 2009, which stipulated that all countries should reduce $\mathrm{CO}_{2}$ emissions according to the sizes of their national GDP. In the Copenhagen Accord, China promised to reduce its $\mathrm{CO}_{2}$ emissions per unit of GDP by $40-45 \%$ in 2020 compared to that in 2005, equivalent to a reduction of 4 billion tons of $\mathrm{CO}_{2}$ emissions.

On 3 September 2016, China approved the accession to the Paris Agreement on Climate Change, which was agreed at the end of 2015 and became effective in early 2016, and became one of the 23 parties that completed the ratification agreement. In this agreement, China committed that its $\mathrm{CO}_{2}$ emissions will peak around 2030 and it will strive for the peak as early as possible. Additionally, China promised to reduce its $\mathrm{CO}_{2}$ emissions per unit of GDP by $60-65 \%$ in 2030 compared to that in 2005 and achieve zero $\mathrm{CO}_{2}$ emissions by 2050 .

It should be noted that China's carbon emission reduction commitment is not only a contribution to the global governance of the greenhouse effect, but also helps to spur its own development mode to shift. However, as the biggest developing country, China needs to promote its economic development through inputting a huge amount of energy, especially fossil energy, which will certainly lead to a lot of $\mathrm{CO}_{2}$ emissions. Therefore, it is undoubtedly a challenge for China to achieve the above emission reduction targets without slowing down the pace of development sharply due to a substantial reduction in fossil energy consumption.

From this perspective, it is important for there to be an awareness and understanding of the interrelationships among energy consumption, economic growth, and $\mathrm{CO}_{2}$ emissions in China, so that the government can clearly see and fully appreciate how much effort is required to change the energy consumption structure of China, in order to move forward in determining how much $\mathrm{CO}_{2}$ emissions need to be reduced and how to do it. This study can give answers to the above issues. On the whole, the main contributions of this paper include:

(1) Previous research studies on the nexus among energy consumption, $\mathrm{CO}_{2}$ emissions, and economic growth mainly focused on exploring the overall relationships among variables in a non-specific and all-embracing way. Unlike these past studies, this paper adopts the selected types of fossil energy consumption instead of the total (fossil) energy consumption as explanatory variables, so as to investigate the specific nexus among the variables.

(2) This paper uses related data from China over the period 1965-2015, ensuring the enrichment of the data. Additionally, considering the presence of breaks in the data, a series of econometric methods based on time series analysis are employed, which possesses very rigorous theoretical logic.

The remainder of this study is organized as follows. Section 2 mainly introduces some literature related to the study. Section 3 presents the data and methods adopted in this paper. The empirical results and the interpretations of the results are reported in Section 4. Finally, we summarize the conclusions of this paper and put forward several policy recommendations in Section 5.

\section{Literature Review}

Before examining the interrelationships among energy consumption, economic growth, and $\mathrm{CO}_{2}$ emissions in China, there is a need to draw on the previous research results as references. The earliest research on the relationship between energy consumption and economic growth was completed by Kraft J and Kraft A, and the unidirectional causality running from GNP to energy consumption was found in their study [1]. However, Akarca and Long found that there was no causality between GNP and energy consumption in the USA by changing the time interval of the same data into two years [2]. Subsequently, many scholars focused on exploring the relationship between the two variables.

A summary of literature on the relationship between energy consumption and economic growth is presented in Table 1 to conserve space. The four hypotheses named growth, conservation, feedback, and neutrality are suggested by the literature listed in Table 1. The growth hypothesis suggests that energy consumption is a major factor promoting economic growth and unidirectional causality running from energy consumption to economic growth can be proven, which means that the reduction of energy consumption has a negative impact on economic growth. The conservation hypothesis is 
proven if there is a unidirectional causality from economic growth to energy consumption, indicating that the energy consumption reduction will not affect economic growth unfavorably. The feedback hypothesis reveals that there exists bidirectional causality between energy consumption and economic growth, which means that energy conservation has a significant impact on economic growth and vice versa. The neutrality hypothesis is supported if there exists no causal relationship between energy consumption and economic growth, indicating that a reduction in energy consumption has no adverse influence on economic growth.

Table 1. Literature review on energy-economic nexus.

\begin{tabular}{|c|c|c|c|c|}
\hline Study & Methodology & Period & Country & Findings \\
\hline Kraft J and Kraft A [1] & Granger test & 1947-1974 & USA & Conservation hypothesis \\
\hline Akarca and Long [2] & Granger test & $1947-1974$ & USA & Neutrality hypothesis \\
\hline Glasure and Lee [3] & $\begin{array}{l}\text { Granger test, error } \\
\text { correction model (ECM) }\end{array}$ & 1961-1990 & $\begin{array}{l}\text { South Korea and } \\
\text { Singapore }\end{array}$ & $\begin{array}{l}\text { Feedback hypothesis in both } \\
\text { countries }\end{array}$ \\
\hline Asafu and Adjaye [4] & $\begin{array}{l}\text { Engle-Granger } \\
\text { methodology, ECM }\end{array}$ & 1973-1995 & $\begin{array}{l}\text { Four Southeast Asian } \\
\text { countries }\end{array}$ & $\begin{array}{l}\text { Growth hypothesis in India and } \\
\text { Indonesia, feedback hypothesis } \\
\text { in Philippines and Thailand }\end{array}$ \\
\hline $\begin{array}{l}\text { Wankeun Oha and } \\
\text { Kihoon Lee [5] }\end{array}$ & $\begin{array}{l}\text { C-D production } \\
\text { function, VECM }\end{array}$ & 1978-2000 & South Korea & Feedback hypothesis \\
\hline Akinlo A E [6] & $\begin{array}{c}\text { Autoregressive } \\
\text { distributed lag (ARDL) } \\
\text { approach, Granger test }\end{array}$ & 1980-2003 & $\begin{array}{c}11 \text { Sub-Saharan Africa } \\
\text { Countries }\end{array}$ & $\begin{array}{l}\text { Feedback hypothesis in } \\
\text { Gambia, Ghana and Senegal, } \\
\text { conservation hypothesis in } \\
\text { Sudan and Zimbabwe }\end{array}$ \\
\hline $\begin{array}{c}\text { Apergisa } N \text { and James E } \\
\text { Payne [7] }\end{array}$ & Panel techniques, ECM & $1980-2004$ & $\begin{array}{l}6 \text { Central American } \\
\text { countries }\end{array}$ & Growth hypothesis \\
\hline Belke A et al. [8] & $\begin{array}{c}\text { Panel techniques, } \\
\text { dynamic ordinary least } \\
\text { squares (DOLS) }\end{array}$ & 1981-2007 & $25 \mathrm{OECD}$ countries & Feedback hypothesis \\
\hline Nadia S Ouedraogo [9] & Panel techniques & 1980-2008 & ECOWAS States & $\begin{array}{l}\text { Conservation hypothesis in } \\
\text { short term and growth } \\
\text { hypothesis in the long run }\end{array}$ \\
\hline Dergiades T et al. [10] & $\begin{array}{c}\text { Granger test, non-linear } \\
\text { causality test }\end{array}$ & 1960-2008 & Greece & Growth hypothesis \\
\hline $\begin{array}{c}\text { Streimikienea D et al. } \\
{[11]}\end{array}$ & $\begin{array}{l}\text { Panel techniques, fully } \\
\text { modified ordinary least } \\
\text { squares (FMOLS), DOLS }\end{array}$ & 1995-2012 & 18 EU countries & Growth hypothesis \\
\hline
\end{tabular}

In addition to the above literature on the relationship between energy consumption and economic growth, many researchers have begun to consider $\mathrm{CO}_{2}$ emissions when examining the energy-economic nexus, due to the growing problem of global warming. The Environmental Kuznets curve proposed by Grossman and Krueger [12] is a helpful tool for exploring the relationship between carbon dioxide emissions and economic growth. Generally speaking, there exists a correlation between economic growth and $\mathrm{CO}_{2}$ emissions, as suggested by Ozturk I [13], Saboori B [14], Shahbaz M [15], and Deviren $\mathrm{S} A$ [16]. To be exact, the causalities between $\mathrm{CO}_{2}$ emissions and economic growth were proven to be unidirectional $[17,18]$ or bidirectional $[15,17,19]$. Furthermore, the unidirectional causality from energy consumption to $\mathrm{CO}_{2}$ emissions was proven by Saboori B and Sulaiman J [14], Arouri, M E H et al. [20], and Kasman A and Duman Y S [21], and the bidirectional causality between the two variables was also found by many scholars $[15,17,22,23]$.

Some recent literature has employed more in-depth approaches when examining the relationships among $\mathrm{CO}_{2}$ emissions, energy consumption, and economic growth. For instance, Magazzino $\mathrm{C}$ explored the relationship between real GDP, $\mathrm{CO}_{2}$ emissions, and energy use in the six Gulf Cooperation Council (GCC) countries [24] and South Caucasus and Turkey [25], and a time series approach considering the variables' structural breaks was adopted, involving Zivot and Andrews's (ZA) test, the autoregressive distributed lag (ARDL) approach, the Gregory and Hansen cointegration test, and the Toda and Yamamoto (T-Y) causality test, etc. These papers suggested that the causality results are different for different countries, and therefore that unified energy policies would not be a good 
strategy for widespread implementation. Moreover, the panel vector autoregression (VAR) approach was employed to investigate the relationship between $\mathrm{CO}_{2}$ emissions, economic growth, and energy consumption in Middle Eastern countries [26], South Caucasus and Turkey [27], and Asia-Pacific Economic Cooperation (APEC) countries [28]. The findings revealed that for the six GCC countries, the growth hypothesis was supported while for the reminding four non-GCC countries, the neutrality hypothesis was supported [26]. In addition, for the study considering South Caucasus and Turkey, the empirical results of panel VAR and Impulse-Response Functions (IRFs) suggested that the neutrality hypothesis can be proven [27]. Finally, for APEC countries, the empirical findings illustrated that no causal relationship emerged between real GDP and energy use, suggesting that the neutrality hypothesis held [28].

Specific to China, which is following the trend of energy-saving and ejection-decreasing in its economic development, it has been a hot issue to investigate the relationship between $\mathrm{CO}_{2}$ emissions, energy consumption, and economic growth in recent years, and numerous research results were obtained by the previous researchers. For instance, the cointegration relationships between $\mathrm{CO}_{2}$ emissions, energy consumption, and economic growth was suggested by Fei L et al. [29], Wang S S et al. [30] and Wang S et al. [31]. Among the research studies on the causal relationship between energy consumption and economic growth in China, Fei L et al. [29], Zhang X P et al. [32] and Chang C C [33] indicated that the unidirectional causality running from economic growth to energy consumption was found in China, while Wang S S et al. [30] and Wang S et al. [31] held the opinion that there existed bidirectional causality between the two variables. Additionally, Saboori B and Sulaiman J [17] discovered a unidirectional causality running from coal consumption to output, and Long X et al. [34] thought there were bidirectional relationships between GDP and coal, gas, as well as electricity consumption. When talking about the causalities between $\mathrm{CO}_{2}$ emissions and economic growth, Fei L et al. [29], Chang C C [33], and Xu S C et al. [35] confirmed the evidence of unidirectional causality from GDP to $\mathrm{CO}_{2}$ emissions, while Long X et al. [34] and Zhang $\mathrm{L}$ and Gao J [36] discovered bidirectional causality between GDP and $\mathrm{CO}_{2}$ emissions in their respective studies. Furthermore, some scholars explored the causalities between energy consumption and $\mathrm{CO}_{2}$ emissions in China, and the fact that there was a unidirectional causal relationship from energy consumption to $\mathrm{CO}_{2}$ emissions is supported by many of them (Wang S et al. [31], Zhang X P et al. [32], Long X et al. [34], Xu S C et al. [35]). Correspondingly, Wang S S et al. [30] and Wang S et al. [37] held the view that there was bidirectional causality between energy consumption and $\mathrm{CO}_{2}$ emissions, according to the results of their research studies.

In light of the above literature review, the relationships between total energy consumption or total fossil energy consumption and $\mathrm{CO}_{2}$ emissions have been examined by numerous scholars, and different results were obtained because of the data obtained for different periods. As there has been a steady increase in the proportion of non-fossil energy, analyzing the linkages between total energy consumption and $\mathrm{CO}_{2}$ emissions seems to be inaccurate. Hence, some researchers have tended to inspect the relationship between fossil energy consumption and $\mathrm{CO}_{2}$ emissions, which greatly reduced the deviations $[17,34]$. However, these studies only focused on the overall linkages between the variables instead of the specific points that they interconnect, such as the casual relationships between $\mathrm{CO}_{2}$ emissions and some sort of fossil energy consumption.

In line with the above discussion, this paper aims to explore the interactions among $\mathrm{CO}_{2}$ emissions, economic growth, and the consumption of selected types of fossil energy (coal, oil, and gas) in China during the period 1965-2015. The stationarities of variables are tested firstly using unit root test techniques. Then, the Johansen cointegration test and vector error-correction model (VECM) are employed to describe the long-run relationship and short error correction mechanism among the analyzed variables. Furthermore, considering the non-stationarity of the analyzed variables, this study inspects the existence and the direction of the causalities between the analyzed variables applying the Granger causality test based on VECM. 


\section{Data and Methodology}

\subsection{Data and Variables}

There are five variables involved in this study, namely, $\mathrm{CO}_{2}$ emissions (CE), real GDP, coal consumption, oil consumption, and gas consumption. The data used here are time series data from China over the period 1965-2015. We obtained the $\mathrm{CO}_{2}$ emissions (Million tonnes, $\mathrm{Mt}$ ) and the consumption of selected types of fossil energy (Million tonnes of oil equivalent, Mtoe) from BP Statistical Review of World Energy 2016. The normal GDP is collected from the website of China National Bureau of Statistics (http:/ / data.stats.gov.cn) and then converted into the real GDP on the basis of 1965 constant prices. To avoid violent fluctuations in the data and eliminate the heterodyne phenomenon in the time series, all variables are converted in their natural logarithmic series. Meanwhile, the coefficients of the logarithmic model can represent the elasticity of variables. The logarithmic variables are expressed as LnCE, LnGDP, LnCoal, LnGas, and LnOil, and the empirical section is accomplished by Eviews 8.0 (North China Electric Power University, Beijing, China).

Table 2 reports the descriptive statistics for all variables. The mean values of all variables are positive. The variables show similar values for mean and median in China, and the $p$ values of all variables' JB statistics are greater than 0.05 , indicating that the normal distributions of all variables emerge.

Table 2. Exploratory data analyses.

\begin{tabular}{ccccccccc}
\hline & Mean & Median & IQR & Max. & Min. & SD & JB & Prob. \\
\hline LnCE & 7.7614 & 7.7495 & 1.1154 & 9.1232 & 6.1656 & 0.8690 & 1.6164 & 0.4457 \\
LnGDP & 6.2258 & 6.2628 & 1.1845 & 7.5819 & 4.6820 & 0.8648 & 1.9960 & 0.3686 \\
LnCoal & 2.7639 & 2.6518 & 0.9617 & 5.1795 & 0.0227 & 1.2776 & 0.1491 & 0.9281 \\
LnGas & 4.7934 & 4.6675 & 2.2971 & 7.0401 & 2.8433 & 1.3192 & 3.6217 & 0.1635 \\
LnOil & 4.7920 & 4.7358 & 1.1681 & 6.3274 & 2.3943 & 1.0168 & 2.7258 & 0.2559 \\
\hline
\end{tabular}

The line chart of the five variables is shown as Figure 1, from which it can be inferred that all variables' curves are smooth. Besides, given the fact that for each variable the 10-Trim value is near to the mean and, additionally that the standard deviation is near to the pseudo-standard deviation, the inter-quartile range (IQR) shows the absence of outliers in the observed sample.
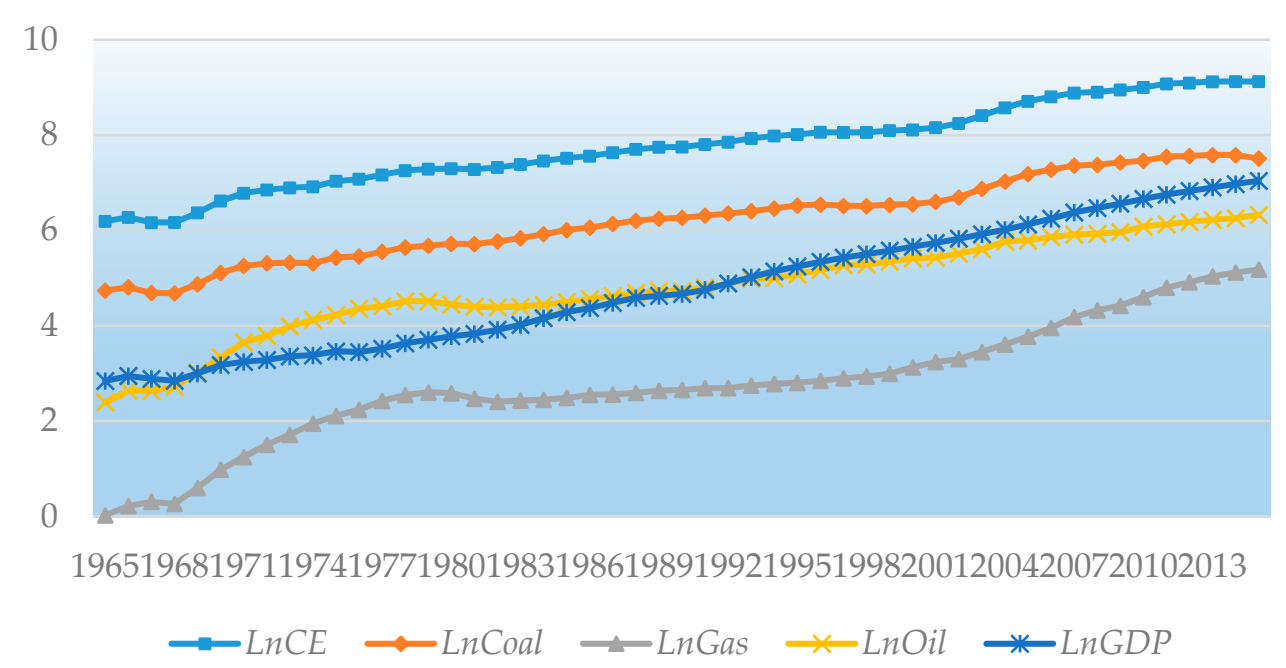

Figure 1. The line chart of the five variables. $L n C E$, LnCoal, LnGas, LnOil and LnGDP are the natural logarithms of $\mathrm{CO}_{2}$ emissions (CE), coal consumption (Coal), gas consumption (Gas), oil consumption (Oil) and gross domestic product (GDP), respectively. 


\subsection{Unit Toot Test}

A time series whose mean or covariance changes over the course of time is non-stationary, and if the first difference of this sequence is stationary, it can be believed that this sequence is integrated of order 1, called I(1). Similarly, if a time series is stationary after $d$ times of difference, we deem that it is integrated of order $d$, called $\mathrm{I}(d)$. To avoid the spurious regression caused by the non-stationarity of data, it is usually necessary to conduct a time series stationary test, mainly the unit root test.

The four types of unit root test methods, namely, Augmented Dickey-Fuller (ADF) [38], Dickey-Fuller generalized least squares (DF-GLS) [39], Kwiatkowski-Philips-Schmidt-Shin (KPSS) [40] and Phillips-Perron (PP) [41] tests, are applied to investigate the stationarity of the time series data in this paper. However, the four types of unit root test methods do not consider the presence of breaks in the data, which may cause the results to be misleading. Thus, this paper also checked if any of the variables have structural breaks. To this extent, the Zivot and Andrews's [42] unit root tests were performed.

\subsection{Johansen Cointegration Test}

The Johansen cointegration test, proposed by Johansen in 1988 [43], is mainly used to judge whether there is a cointegration relationship among time series with the same order integration; that is, whether the liner combination of these time series is stationary. Unlike Engle-Granger cointegration, the Johansen cointegration test can be used for more than two time series. Johansen cointegration depends on the regression coefficients, and its basic idea is to transform the issue of seeking the maximum likelihood function into the problem of finding the characteristic root and the corresponding eigenvector using vector autoregression (VAR) model. Suppose the VAR model without a moving average item can be expressed as follow:

$$
\mathbf{y}_{\mathbf{t}}=\prod_{1} \mathbf{y}_{\mathbf{t}-\mathbf{1}}+\ldots+\prod_{p} \mathbf{y}_{\mathbf{t}-\mathbf{p}}+\mu_{\mathbf{t}}
$$

where $\mathbf{y}_{\mathbf{t}}$ is a vector including $k$ processes of $\mathrm{I}(1)$, $\mathbf{u}_{\mathbf{t}}$ is a vector of $k \times 1$, and $\Pi_{j}$ is a coefficient matrix of $k \times k$. We obtain the following model by differencing the Equation (7):

$$
\Delta \mathbf{y}_{\mathbf{t}}=\sum_{j=1}^{p} \Psi_{j} \Delta \mathbf{y}_{\mathbf{t}-\mathbf{j}}+\prod \mathbf{y}_{\mathbf{t}-\mathbf{1}}+\boldsymbol{\mu}_{\mathbf{t}}
$$

where $\mathbf{\Psi}_{\mathbf{j}}=-\sum_{i=j+1}^{p} \prod_{i}, j=1,2, \ldots, p-1, \Pi=\sum_{i=1}^{p} \prod_{i}-\mathrm{I}$.

According to the cointegration theory, if $\Delta \mathbf{y}_{\mathbf{t}}$ is I(0), then $\Pi y_{t-1}$ is I(0) too. Thus, we can determine whether the cointegration relationship exists by testing the rank of $\Pi$. If $\operatorname{rank}(\Pi)=0$ or $\operatorname{rank}(\Pi)=k$, it means that there exists no cointegration relationship in $\mathrm{y}_{\mathrm{t}}$, and $\operatorname{rank}(\Pi)=r<k$ indicates that $\mathrm{y}_{\mathrm{t}}$ is cointegrated. Commonly, we employ Trace and Maximum Eigenvalue statistics to define the degree of cointegration between variables with the same order integration.

\subsection{Vector Error-Correction Model (VECM)}

The following model can be obtained by decomposing $\Pi$ in Equation (8) into the product of two vectors:

$$
\Delta \mathbf{y}_{\mathbf{t}}=\boldsymbol{\alpha} \boldsymbol{\beta}^{\prime} \mathbf{y}_{\mathbf{t}-\mathbf{1}}+\sum_{j=1}^{p} \mathbf{\Psi}_{j} \Delta \mathbf{y}_{\mathbf{t}-\mathbf{j}}+\boldsymbol{\mu}_{\mathbf{t}}
$$

where $\Pi=\alpha \beta^{\prime}$. A further consolidation to the Formula (9) helps us get the model as follow:

$$
\Delta \mathbf{y}_{\mathbf{t}}=\alpha \mathbf{e c m}_{\mathbf{t}-1}+\sum_{j=1}^{p} \mathbf{\Psi}_{j} \Delta \mathbf{y}_{\mathbf{t}-\mathbf{j}}+\boldsymbol{\mu}_{\mathbf{t}}
$$


where $\mathbf{e c m}_{\mathbf{t}-\mathbf{1}}=\beta^{\prime} \mathbf{y}_{\mathbf{t}-1}$ represents the error correction item reflecting the long-term equilibrium relationship among the variables. Coefficient $\alpha$ denotes the adjustment speed of the VECM when the short-term fluctuations deviate from the long-run equilibrium. The coefficients of variables' differential items on the right of the equations reflect the impact of variables' short-term fluctuations on the short-term changes of the explanatory variable. Thus, each equation we obtained in Formula (10) is called an error correction model, and all of these equations are collectively called the vector error correction model (VECM).

\subsection{Granger Causality Test Based on VECM}

Granger proposed a kind of causality based on "prediction" called Granger causality (actually, it indicates non-causality between variables) in 1969 [44], and now it is generally accepted and widely used by most economists as an econometric approach after he developed this theory in 1980 and $1988[45,46]$. The Granger non-causality between $\mathbf{x}_{\mathbf{t}}$ and $\mathbf{y}_{\mathbf{t}}$ should be recognized when $\mathbf{y}_{\mathbf{t}}$ 's conditional distribution determined by the hysteresis values of $\mathbf{y}_{\mathbf{t}}$ is the same as its conditional distribution determined by the hysteresis values of $\mathbf{y}_{\mathbf{t}}$ and $\mathbf{x}_{\mathbf{t}}$. In other words, if

$$
f\left(\mathbf{y}_{\mathbf{t}} \mid \mathbf{y}_{\mathbf{t}-1}, \ldots, \mathbf{x}_{\mathbf{t}-1}, \ldots\right)=f\left(\mathbf{y}_{\mathbf{t}} \mid \mathbf{y}_{\mathbf{t}-1}, \ldots\right)
$$

we deem that there exists no Granger causality running from $\mathbf{x}_{\mathbf{t}}$ to $\mathbf{y}_{\mathbf{t}}$.

Suppose a VAR model involving two variables named $\mathbf{x}_{\mathbf{t}}$ and $\mathbf{y}_{\mathbf{t}}$ is expressed as below:

$$
\mathbf{y}_{\mathbf{t}}=\sum_{i=1}^{k} \alpha_{\mathbf{i}} \mathbf{y}_{\mathbf{t}-\mathbf{i}}+\sum_{i=1}^{k} \beta_{\mathbf{i}} \mathbf{x}_{\mathbf{t}-\mathbf{i}}+\boldsymbol{\mu}_{\mathbf{t}}
$$

We can judge the existence of the causal relationship running from $\mathbf{x}_{\mathbf{t}}$ to $\mathbf{y}_{\mathbf{t}}$ via inspecting whether we could weed out all the hysteresis values of $\mathbf{x}_{\mathbf{t}}$ from the Equation (12), so as to make $\mathbf{y}_{\mathbf{t}}$ a dependent variable. Thus, the null hypothesis of the Granger causality test is: $\mathrm{H}_{0}: \beta_{1}=\beta_{2}=\ldots=\beta_{k}=0$, which indicates that there is not Granger causality running from $\mathbf{x}_{\mathbf{t}}$ to $\mathbf{y}_{\mathbf{t}}$. The alternative hypothesis is $\mathrm{H}_{1}$ : there exists $p(1 \leq p \leq k)$ making $\beta_{\mathbf{p}} \neq \mathbf{0}$, which means the unidirectional causality running from $\mathbf{x}_{\mathbf{t}}$ to $\mathbf{y}_{\mathbf{t}}$ is recognized.

If the variables are stationary, the $\boldsymbol{F}$ test is available to judge the causal relationship between variables. Otherwise, performing the Granger test on variables directly may cause false regression, which is untrustworthy $[47,48]$. Actually, the variables in the VECM are stationary, which guarantees the validity of the Granger causality test. Therefore, in this paper we will adopt the $\boldsymbol{F}$ test to test for causal relationships if the variables are stationary. On the contrary, we will employ the Granger causality test based on VECM to investigate causal relationships between the variables if they are non-stationary $[49,50]$.

\section{Empirical Results and Interpretations}

In this section, the empirical results obtained by econometric analysis techniques and the interpretations of these results will be reported. First of all, the stationarity of the data we adopted is examined via unit root test, and then the Johansen cointegration test is employed to verify the existence of the cointegrating relationship among the variables. After that, the VECM is exploited to investigate the error correction mechanism of the system involving five variables. Finally, the Granger causality test based on VECM is applied to explore causal relationships between the variables.

\subsection{Unit Toot Test}

The ADF and PP tests are employed to check whether the time series data are stationary. The optimal numbers of variables' lags are determined by Schwarz Information Criterion (SIC) for ADF and DF-GLS tests and the bandwidth is chosen by the Neweye-West method for PP and KPSS 
tests. The unit root test results are shown in Table 3, from which it is concluded that ADF, DF-GLS, KPSS, and PP tests all support the fact that the variables analyzed are non-stationary in level, but stationary in their first difference.

Table 3. Unit root test results.

\begin{tabular}{ccccc}
\hline Variables & ADF & DF-GLS & KPSS & PP \\
\hline LnCE & $-3.174(-3.504)$ & $-3.084(-3.190)$ & $0.191^{* *}(0.146)$ & $-2.124(-3.502)$ \\
LnGDP & $-2.868(-3.504)$ & $-2.188(-3.190)$ & $0.203^{* *}(0.146)$ & $-2.910(-3.502)$ \\
LnCoal & $-3.488(-3.504)$ & $-3.424(-3.190)$ & $0.178^{* *}(0.146)$ & $-2.155(-3.502)$ \\
LnGas & $-2.120(-3.504)$ & $-1.837(-3.190)$ & $0.158^{* *}(0.146)$ & $-1.933(-3.502)$ \\
LnOil & $-2.556(-3.504)$ & $-1.521(-3.190)$ & $0.166^{* *}(0.146)$ & $-3.025(-3.502)$ \\
$\Delta$ LnCE & $-3.819^{* * *}(-2.922)$ & $-3.809^{* * *}(-1.948)$ & $\left.0.101^{* *}(0.463)\right)$ & $-3.243^{* *}(-2.922)$ \\
$\Delta$ LnGDP & $-4.955^{* * *}(-2.922)$ & $-6.720^{* * *}(-1.948)$ & $0.351^{*}(0.463)$ & $-4.776^{* * *}(2.922)$ \\
$\Delta$ LnCoal & $-3.687^{* * *}(-2.922)$ & $-3.743^{* * *}(-1.948)$ & $0.086(0.463)$ & $-3.190^{* *}(2.922)$ \\
$\Delta$ LnGas & $-2.972^{* *}(-2.922)$ & $-2.658^{* * *}(-1.948)$ & $0.174(0.463)$ & $-2.971^{* *}(2.922)$ \\
$\Delta$ LnOil & $-3.973^{* * *}(-2.922)$ & $-1.984^{* *}(-1.948)$ & $0.334(0.463)$ & $-4.053^{* * *}(2.922)$ \\
\hline
\end{tabular}

Notes: All tests include time trend and intercept at level but only intercept at the first difference. $5 \%$ Critical Values are given in parentheses. ${ }^{*} p<0.1 .{ }^{* *} p<0.05 .{ }^{* * *} p<0.01$. ADF: Augmented Dickey-Fuller; DF-GLS: Dickey-Fuller generalized least squares; KPSS: Kwiatkowski-Philips-Schmidt-Shin; PP: Phillips-Perron.

As mentioned before, the presence of breaks in the data may cause the above unit root test results to be misleading. Therefore, Zivot and Andrews's (ZA) unit root test is performed in order to consider the potential structural breaks. The results of the ZA test are presented in Table 4, and the null hypothesis of the $\mathrm{ZA}$ test is $\mathrm{H}_{0}$ : the variable has a unit root with a structural break. There are three types of ZA model, and the variable is considered to be non-stationary as long as the null hypothesis of any model cannot be rejected. However, if the null hypotheses of all of the three models are rejected, it cannot be concluded that the variable is stationary, because the variable may have a unit root without a structural break. In this case, the abovementioned four unit root tests, ADF, PP, DF-GLS, and KPSS, will judge the variable's stationarity.

Table 4. Results of unit root with structural breaks tests.

\begin{tabular}{cccc}
\hline Variables & ZA(a) & ZA(b) & ZA(c) \\
\hline LnCE & $-4.8146^{* * *}[2003]$ & $-2.9475^{*}[1979]$ & $-3.6544^{* * *}[2003]$ \\
LnGDP & $-7.1188^{* * *}[1976]$ & $-6.3076[1982]$ & $-7.4460^{* * *}[1976]$ \\
LnCoal & $-3.7589^{* 1996]}$ & $-3.6354[2000]$ & $-3.8690[2005]$ \\
LnGas & $-7.5479^{*}[2005]$ & $-9.1562^{* * *}[1998]$ & $-8.5267^{* * *}[2003]$ \\
LnOil & $-6.0969^{* *}[1990]$ & $-5.1872^{* * 2002]}$ & $-5.1856[2003]$ \\
$\Delta$ LnCE & $-4.0190^{* *}[2002]$ & $-3.0117^{* *}[2007]$ & $-5.1487^{* * *}[2003]$ \\
$\Delta$ LnGDP & $-7.4820^{* *}[1982]$ & $-5.6445^{* *}[1985]$ & $-5.3523^{* *}[1982]$ \\
$\Delta$ LnCoal & $-5.7689^{* *}[2002]$ & $-5.1412^{* *}[2007]$ & $-7.7864^{* * *}[2003]$ \\
$\Delta$ LnGas & $-3.9314^{* *}[1978]$ & $-3.7573^{* * *}[1981]$ & $-4.3374^{* *}[1980]$ \\
$\Delta$ LnOil & $-3.7178^{* *}[1977]$ & $-4.3966^{* * *}[1981]$ & $-6.6595^{* * *}[1984]$ \\
\hline
\end{tabular}

Notes: ZA: Zivot and Andrews's unit root test; ZA(a): model allowing for break in intercept; ZA(b): model allowing for break in trend. $\mathrm{ZA}(\mathrm{c})$ : model allowing for break in intercept and trend. Break points in square brackets. ${ }^{*} p<0.1$. ${ }^{* *} p<0.05 .{ }^{* * *} p<0.01$.

In Table 4, all variables are proven to be non-stationary at level, since the null hypothesis of ZA test cannot be rejected at a 5\% significance level. After taking the first difference, the null hypothesis is rejected, indicating that all variables do not have the unit roots with structural breaks. When combined with results in Table 3, it can be inferred that the five variables analyzed are non-stationary at level, but stationary at their first difference. It can therefore be concluded that the variables explored are integrated of order one, that is, I(1). 


\subsection{Johansen Cointegration Test}

The Johansen cointegration test can provide evidence that directly indicates whether the variables are cointegrated or not. This paper exploited Trace and Maximum Eigenvalue (Max-Eigen) tests to judge the existence of the long-run equilibrium relationship among $\mathrm{CO}_{2}$ emissions, GDP, and the consumption of coal, gas, and oil. Before performing the Johansen cointegration test, an unrestricted VAR model including five variables was constructed, and the optimal lag of VAR model determined by SIC was 2 . With the selected lag length, there exists no autocorrelation in the model, as suggested by the results of autocorrelation Lagrange multiplier (LM) test (Table 5).

Table 5. Results of autocorrelation LM test.

\begin{tabular}{ccccccccc}
\hline Lags & $\mathbf{1}$ & $\mathbf{2}$ & $\mathbf{3}$ & $\mathbf{4}$ & $\mathbf{5}$ & $\mathbf{6}$ & $\mathbf{7}$ & $\mathbf{8}$ \\
\hline LM-Stat. & 30.2968 & 19.7071 & 21.6945 & 18.4680 & 27.1804 & 13.9877 & 13.5988 & 22.2143 \\
Prob. & 0.2134 & 0.7620 & 0.6533 & 0.8219 & 0.3469 & 0.9619 & 0.9683 & 0.6233 \\
\hline
\end{tabular}

Thus, we set the optimal hysteresis order of the Johansen cointegration test to 1 . Moreover, the form of Data Generating Process (DGP) in Johansen cointegrating is the fourth one, determined by SIC. Table 6 reports the results of the Trace and Max-Eigen test, which indicate that two cointegrating relationships among the variables were found.

Table 6. Results of Johansen cointegration test for Trace and Max-Eigen test.

\begin{tabular}{cccccc}
\hline \multirow{2}{*}{$\begin{array}{c}\text { Hypothesized } \\
\text { No. of CE(s) }\end{array}$} & \multirow{2}{*}{ Eigenvalue } & \multicolumn{2}{c}{ Trace Test } & \multicolumn{2}{c}{ Max-Eigen Test } \\
\cline { 3 - 5 } & & Statistic Value & Prob. ${ }^{* *}$ & Statistic Value & Prob. $^{* *}$ \\
\hline None & 0.725535 & 139.4503 & $0.0000^{*}$ & 63.35371 & $0.0000^{*}$ \\
At most 1 & 0.576461 & 76.09654 & $0.0034^{*}$ & 42.09635 & $0.0022^{*}$ \\
At most 2 & 0.278698 & 34.00019 & 0.2885 & 16.00816 & 0.5439 \\
At most 3 & 0.217562 & 17.99203 & 0.3444 & 12.02169 & 0.4132 \\
\hline
\end{tabular}

Notes: * Denotes rejection of the null hypothesis at the 0.05 level. ${ }^{* *}$ MacKinnon-Haug-Michelis (1999) $p$-values.

The standard cointegration equation which reflects the long-run equilibrium among the variables is expressed as below (standard errors in parentheses):

$$
\begin{array}{cccc}
L n C E_{\mathrm{t}}= & 0.300 \operatorname{LnGDP} P_{\mathrm{t}}+0.722 \operatorname{LnCoal_{\mathrm {t}}}+0.048 \operatorname{LnGas}_{\mathrm{t}}+0.148 \operatorname{LnOil}_{\mathrm{t}}-0.025 \mathrm{t} \\
(0.03435) & (0.01895) & (0.00713) & (0.01150)
\end{array}
$$

The evidence obtained from this equation indicates that economic growth and the consumption of selected types of fossil energy will promote the significant increase of $\mathrm{CO}_{2}$ emissions. As shown in Formula (7), in the long run, coal consumption has the largest contribution to $\mathrm{CO}_{2}$ emissions, followed by economic growth, oil consumption, and gas consumption. Specifically speaking, a $1 \%$ increase in coal consumption will increases $\mathrm{CO}_{2}$ emissions by $0.722 \%$, and a $1 \%$ increase in GDP, oil consumption, and gas consumption will respectively increase $\mathrm{CO}_{2}$ emissions by $0.300 \%, 0.148 \%$, and $0.048 \%$. Additionally, it should be noted that the $\mathrm{CO}_{2}$ emissions may decrease gradually by $0.025 \%$ as time passes, which can be considered as the natural abatement effect.

\subsection{Vector Error-Correction Model (VECM)}

To investigate how the short-term fluctuations of the variables affect the long-run equilibrium, a VECM containing five variables based on the VAR model is developed, and the error correction items are reported as follows:

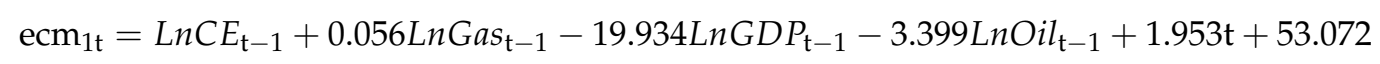




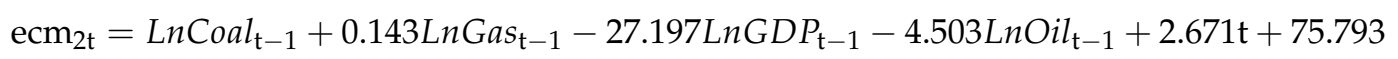

Therefore, the estimation results of VECM with two error correction items are listed in Table 7. As shown in Table 7, five VECMs are obtained based on the Johansen cointegration test results. The coefficients of error correction items are significant, except for the coefficients of $\mathrm{ecm}_{1 \mathrm{t}}$ in $\mathrm{D}\left(\operatorname{LnCoal}_{\mathrm{t}}\right)^{\prime} \mathrm{s}$ VECM and $\mathrm{ecm}_{2 \mathrm{t}}$ in $\mathrm{D}\left(\operatorname{LnC} E_{\mathrm{t}}\right)^{\prime} \mathrm{s}$ VECM. Specifically speaking, for $\mathrm{D}\left(\operatorname{LnC} E_{\mathrm{t}}\right)^{\prime} \mathrm{s}$ VECM, the coefficient of error correction item is greater than 0 (this paper does not consider the error correction item that is not significant), indicating that the error correction mechanism does not have a convergence effect on the change of $\mathrm{CO}_{2}$ emissions. For $\mathrm{D}\left(\mathrm{LnCoal}_{\mathrm{t}}\right)^{\prime} \mathrm{s} \mathrm{VECM}$, the coefficient of the error correction

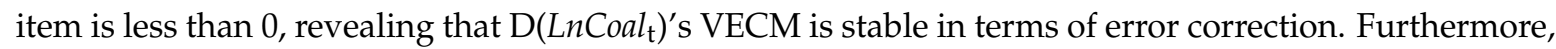
the coefficients of the error correction items in each remaining fossil energy's VECM are both positive and negative. The error correction mechanism with a positive coefficient will promote the continuous increases of oil and gas consumption, while the other error correction mechanism with a negative coefficient will have convergence effects on the changes of oil and gas consumption. Therefore,

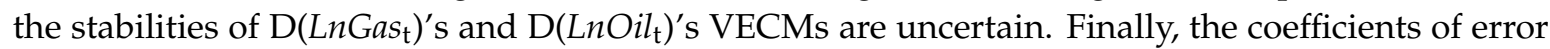

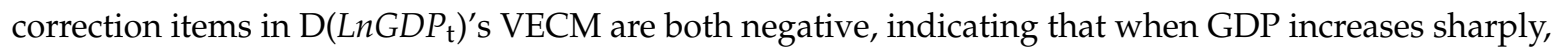
the error correction mechanisms will decrease the increase rate of future GDP to make the system return back to the equilibrium shown in the standard cointegration Equation (7).

Table 7. Estimation results of VECM with two error correction items (standard errors in parentheses).

\begin{tabular}{|c|c|c|c|c|c|}
\hline Error Correction & $\mathrm{D}\left(\operatorname{LnC} E_{\mathrm{t}}\right)$ & $\mathrm{D}\left(\right.$ LnCoal $\left._{\mathrm{t}}\right)$ & $\mathrm{D}\left(\operatorname{LnG}_{a} s_{\mathfrak{t}}\right)$ & $\mathrm{D}\left(\mathrm{LnOil}_{\mathrm{t}}\right)$ & $\mathrm{D}\left(\operatorname{LnGDP} P_{\mathrm{t}}\right)$ \\
\hline$e c m_{1 t}$ & $\begin{array}{l}0.9282 * \\
(0.4787)\end{array}$ & $\begin{array}{c}-0.1592 \\
(0.3071)\end{array}$ & $\begin{array}{l}1.3819 * \\
(0.7117)\end{array}$ & $\begin{array}{c}-2.1236^{*} \\
(0.6568)\end{array}$ & $\begin{array}{c}-0.6324 \text { * } \\
(0.3396)\end{array}$ \\
\hline $\mathrm{ecm}_{2 \mathrm{t}}$ & $\begin{array}{c}0.2625 \\
(0.3483)\end{array}$ & $\begin{array}{c}-0.8417 \text { * } \\
(0.3689)\end{array}$ & $\begin{array}{c}-1.0001 \text { * } \\
(0.4178)\end{array}$ & $\begin{array}{l}1.5537 * \\
(0.4779)\end{array}$ & $\begin{array}{c}-0.4382 \\
(0.2471)\end{array}$ \\
\hline $\mathrm{D}\left(\operatorname{LnC} E_{\mathrm{t}-1}\right)$ & 0.4592 & 0.6247 & -0.5119 & 1.5475 & -0.1370 \\
\hline $\mathrm{D}(\operatorname{LnCoal} \mathrm{t}-1)$ & 0.3458 & 0.0429 & -0.6810 & -0.7783 & -0.0503 \\
\hline $\mathrm{D}\left(\operatorname{Ln} G a s_{\mathrm{t}-1}\right)$ & 0.3071 & -0.3002 & 0.3300 & -0.2869 & 0.1904 \\
\hline $\mathrm{D}\left(\operatorname{LnOil}_{\mathrm{t}-1}\right)$ & 0.1785 & -0.1365 & -0.8798 & 0.1811 & 0.2907 \\
\hline $\mathrm{D}\left(\operatorname{Ln} G D P_{\mathrm{t}-1}\right)$ & -0.4881 & 0.5116 & 0.8129 & 0.3705 & 0.1927 \\
\hline C & 0.0231 & 0.0214 & 0.0572 & 0.0434 & 0.0358 \\
\hline
\end{tabular}

Note: ${ }^{*}$ Denotes rejection of the null hypothesis at the 0.05 level.

In the short term, (1) the increases of in fossil energy (coal, gas, and oil) consumption will expand the increase of $\mathrm{CO}_{2}$ emissions while the increases of GDP will retard the increase of $\mathrm{CO}_{2}$ emissions, revealing that $\mathrm{CO}_{2}$ emissions may increase more slowly or even decrease as GDP increases, supposing fossil energy consumption increases gently. (2) The increase of GDP will promote the increase of coal consumption while the increases of oil and gas consumption will slow down the increase of coal consumption, which reflects the substitution effects of oil and gas on coal. Similarly, the increase of GDP will promote the increases of oil and gas consumption and there are also substitution effects between gas and oil. (3) The changes in gas and oil consumption will promote a change in GDP, indicating that China's economic growth depends a lot on energy input. In contrast, the changes in $\mathrm{CO}_{2}$ emissions and coal consumption have negative effects on GDP's change (the effect of coal consumption is slight), revealing that $\mathrm{CO}_{2}$ emissions have become an important factor restricting China's economic development.

It can be inferred from the VECM that the error correction mechanism of the system cannot prevent the continued increases of $\mathrm{CO}_{2}$ emissions and the consumption of the selected types of fossil energy, revealing that reducing the $\mathrm{CO}_{2}$ emissions and changing the energy consumption structure of China based on the automatic adjustment function of the system are unfeasible. Therefore, some relevant government interventions are imperative. 


\subsection{Granger Causality Test Based on VECM}

As mentioned before, the presence of Granger causality between two variables reveals that one variable's past values have significant effects on the future level of another variable. Usually, Granger causality has three types, named bidirectional causality, unidirectional causality, and no causality. Considering the non-stationarity of the variables analyzed, this paper employs the Granger causality test based on VECM to investigate the existence and direction of the causal relationships between the five variables.

The results of the Granger causality test based on VECM are represented in Table 8. As listed in Table 8, (1) bidirectional causalities between GDP and coal consumption, between GDP and gas consumption, and between coal consumption and $\mathrm{CO}_{2}$ emissions were found, indicating that coal and gas consumption will keep increasing as the Chinese economy develops, and that $\mathrm{CO}_{2}$ emissions are to increase in the future. (2) The results of the Granger causality test support that unidirectional causalities running from GDP and oil consumption to $\mathrm{CO}_{2}$ emissions are found, which reveals that economic growth and oil consumption have significant and positive impacts on $\mathrm{CO}_{2}$ emissions. (3) The unidirectional causality running from GDP to oil consumption is also found in this study. It can be inferred that the consumption of oil will still increase as the constant growth of Chinese economy in the predicted future, which is obviously unsustainable. (4) The unidirectional causalities running from coal consumption to oil and gas consumption are found, supporting the existence of the substitution effect of coal on oil and gas.

Table 8. Result of Granger causality test based on VECM ( $p$-values in parentheses).

\begin{tabular}{cccccc}
\hline & $\mathbf{D}($ LnCE $)$ & $\mathbf{D}($ LnCoal $)$ & $\mathbf{D}($ LnGas $)$ & $\mathbf{D}($ LnOil $)$ & $\mathbf{D}($ LnGDP $)$ \\
\hline \multirow{2}{*}{$\mathrm{D}($ LnCE $)$} & & 4.405012 & 0.160418 & 1.721115 & 0.050457 \\
& & $(0.0358)^{*}$ & $(0.6888)$ & $(0.1895)$ & $(0.8223)$ \\
\hline \multirow{2}{*}{$\mathrm{D}($ LnCoal $)$} & 5.168438 & & 5.714742 & 7.684880 & 8.010720 \\
& $(0.0230) *$ & & $(0.0168)^{*}$ & $(0.0056)^{*}$ & $(0.0047)^{*}$ \\
\hline \multirow{2}{*}{$\mathrm{D}($ LnGas $)$} & 0.004457 & 0.470661 & & 2.396794 & 3.947911 \\
& $(0.9468)$ & $(0.4927)$ & & $(0.1216)$ & $(0.0469)^{*}$ \\
\hline \multirow{2}{*}{$\mathrm{D}($ LnOil $)$} & 4.519722 & 0.270922 & 0.446636 & & 2.740576 \\
& $(0.0335) *$ & $(0.6027)$ & $(0.5039)$ & & $(0.0978)$ \\
\hline \multirow{2}{*}{$\mathrm{D}($ LnGDP $)$} & 6.263762 & 6.134820 & 7.863377 & 4.917525 & \\
& $(0.0123) *$ & $(0.0133) *$ & $(0.0050) *$ & $(0.0266)^{*}$ & \\
\hline
\end{tabular}

Note: ${ }^{*}$ Denotes rejection of the null hypothesis at the 0.05 level.

Generally speaking, the results of the Granger causality test show that the consumption of coal and oil will Granger cause $\mathrm{CO}_{2}$ emissions while gas cannot, and this may be because coal and oil produce more $\mathrm{CO}_{2}$ when burning compared with gas. In addition, coal and gas consumption can Granger cause GDP while oil cannot, and this may be a result of the Chinese economy being more dependent on coal than other energy sources, and due to China vigorously promoting the use of gas. As suggested by Granger causality test's results, GDP can cause the consumption of selected types of fossil energy and $\mathrm{CO}_{2}$ emissions, revealing that China should make great efforts to change its energy-dependent development pattern, so as to fulfill its promise of reducing its carbon emissions drastically in the next 30 years.

\section{Conclusions and Policy Implications}

With the great achievement in economic development in the past several decades, the $\mathrm{CO}_{2}$ emissions of China are simultaneously becoming more and more serious. In this case, China has promised to reduce its carbon emissions drastically in the next 30 years. Therefore, it is worth exploring the nexus between $\mathrm{CO}_{2}$ emissions, economic growth, and energy consumption (especially the selected 
types of fossil energy consumption) in China. In this paper, related data from 1965 to 2015 were collected to complete the above objectives by employing econometric techniques.

Some meaningful results were obtained in this paper via empirical analysis. Firstly, unit root testing showed that the five variables examined are non-stationary at level, but stationary at their first difference, and the presence of breaks in the data was also examined, similar to Magazzino C's research studies [27,28]. Secondly, the long-run equilibrium relationships among the analyzed variables were found by the Johansen cointegration test, consistent with the results of Fei L et al. [29] and Wang S S et al. [30], which are based on panel data analyses. Furthermore, the standard cointegration equation of this paper specifically indicates that in the long run, coal consumption is set to represent the largest contribution to $\mathrm{CO}_{2}$ emissions, followed by economic growth, oil consumption, and gas consumption. Thirdly, VECM revealed that the error correction mechanisms of the system can effectively slow the growth of coal consumption but cannot stop the continued increases of $\mathrm{CO}_{2}$ emissions and the consumption of gas and oil, due to the substitution effects between coal, gas, and oil; as such, government interventions are imperative. Finally, the Granger causality test based on VECM reports bidirectional causalities between GDP and coal consumption, between coal consumption and $\mathrm{CO}_{2}$ emissions, and between GDP and gas consumption, and unidirectional causalities running from GDP and oil consumption to $\mathrm{CO}_{2}$ emissions and from GDP to gas and oil consumption, which are partially consistent with the results of Wang S et al. [31], Zhang X P et al. [32], Chang C C [33] and Long $X$ et al. [34]. Additionally, differing from the previous studies, unidirectional casual relationships running from coal consumption to oil and gas consumption are found in this paper, verifying the VECM's results in regard to existing substitution effects between the selected types of fossil energy.

According to the empirical results, several policy implications are proposed. As reported in the standard cointegration Equation (7), coal, oil, and gas consumption significantly promote $\mathrm{CO}_{2}$ emissions and thereby have important implications for the implementation of future policies centered on changing China's energy consumption structure by reducing the consumption of fossil energy. Furthermore, the empirical results show that GDP has a significant and positive effect on $\mathrm{CO}_{2}$ emissions, indicating that China's current pattern of economic growth is undesirable, therefore it is urgent for China to change its energy-dependent economic growth mode, which is fortunately in the process of occurring. Moreover, the VECM results show that the increases of fossil energy consumption help to promote the increase of $\mathrm{CO}_{2}$ emissions while the increase of GDP can retard the increase rate of $\mathrm{CO}_{2}$ emissions in the short term. The Granger causality test results show that gas cannot Granger cause $\mathrm{CO}_{2}$ emissions, but can Granger cause GDP, demonstrating the need for the formulation and execution of policies to strengthen the proportion of gas in the fossil energy consumption, as the total consumption of fossil fuels cannot be reduced in a rapid time frame.

Acknowledgments: Thanks are due to the North China Electric Power University Library for providing detailed reference for our research and to Sen Guo for proofreading the language of this paper.

Author Contributions: Li Hongze and Li Bingkang conceived and designed the research method used in this paper; Lu Hao collected the data used for empirical analysis; Li Bingkang performed the empirical analysis and wrote the paper.

Conflicts of Interest: The authors declare no conflict of interest.

\section{References}

1. Kraft, J.; Kraft, A. On the relationship between energy and GNP. J. Energy Dev. 1978, 3, 401-403.

2. Akarca, A.T.; Long, V. On the relationship between energy and GNP: A re-examination. J. Energy Dev. 1980, 5, 326-331.

3. Glasure, Y.U.; Lee, A.R. Cointegration, error-correction, and therelationship between GDP and Energy: The case of South Korea and Singapore. Resour. Energy Econ. 1997, 20, 17-25. [CrossRef]

4. Asafu-Adjaye, J. The relationship between energy consumption, energy prices and economic growth: Time series evidence from Asian developing countries. Energy Econ. 2000, 22, 615-625. [CrossRef] 
5. Oh, W.; Lee, K. Energy consumption and economic growth in Korea: Testing the causality relation. J. Policy Model. 2004, 26, 973-981. [CrossRef]

6. Akinlo, A.E. Energy consumption and economic growth: Evidence from 11 Sub-Sahara African countries. Energy Econ. 2008, 30, 2391-2400. [CrossRef]

7. Apergis, N.; Payne, J.E. Energy consumption and economic growth in Central America: Evidence from a panel cointegration and error correction model. Energy Econ. 2009, 31, 211-216. [CrossRef]

8. Belke, A.; Dobnik, F.; Dreger, C. Energy consumption and economic growth: New insights into the cointegration relationship. Energy Econ. 2011, 33, 782-789. [CrossRef]

9. Ouedraogo, N.S. Energy consumption and economic growth: Evidence from the economic community of West African States (ECOWAS). Energy Econ. 2013, 36, 637-647. [CrossRef]

10. Dergiades, T.; Martinopoulos, G.; Tsoulfidis, L. Energy consumption and economic growth: Parametric and non-parametric causality testing for the case of Greece. Energy Econ. 2013, 36, 686-697. [CrossRef]

11. Streimikiene, D.; Kasperowicz, R. Review of economic growth and energy consumption: A panel cointegration analysis for EU countries. Renew. Sustain. Energy Rev. 2016, 59, 1545-1549. [CrossRef]

12. Grossman, G.M.; Krueger, A.B. Economic Growth and the Environment. Available online: http://www.nber. org/papers/w4634 (accessed on 18 April 2017).

13. Ozturk, I.; Acaravci, A. $\mathrm{CO}_{2}$ emissions, energy consumption and economic growth in Turkey. Renew. Sustain. Energy Rev. 2010, 14, 3220-3225. [CrossRef]

14. Saboori B; Sulaiman J. $\mathrm{CO}_{2}$ emissions, energy consumption and economic growth in Association of Southeast Asian Nations (ASEAN) countries: A Cointegration approach. Energy 2013, 55, 813-822.

15. Shahbaz, M.; Hye, Q.M.A.; Tiwari, A.K.; Leitão, N.C. Economic growth, energy consumption, financial development, international trade and $\mathrm{CO}_{2}$ emissions in Indonesia. Renew. Sustain. Energy Rev. 2013, 25, 109-121. [CrossRef]

16. Deviren, S.A.; Deviren, B. The relationship between carbon dioxide emission and economic growth: Hierarchical structure methods. Phys. A Stat. Mech. Appl. 2016, 451, 429-439. [CrossRef]

17. Pao, H.T.; Tsai, C.M. $\mathrm{CO}_{2}$ emissions, energy consumption and economic growth in BRIC countries. Energy Policy 2010, 38, 7850-7860. [CrossRef]

18. Saidi, K.; Mbarek, M.B. Nuclear energy, renewable energy, $\mathrm{CO}_{2}$ emissions, and economic growth for nine developed countries: Evidence from panel Granger causality tests. Prog. Nucl. Energy 2016, 88, 364-374. [CrossRef]

19. Lu, H.; Campbell, D.E.; Sagisaka, M.; Ren, H. Interactions among energy consumption, economic development and greenhouse gas emissions in Japan after World War II. Renew. Sustain. Energy Rev. 2016, 54, 1060-1072. [CrossRef]

20. Arouri, M.E.H.; Youssef, A.B.; M'henni, H.; Rault, C. Energy consumption, economic growth and $\mathrm{CO}_{2}$ emissions in Middle East and North African countries. Energy Policy 2012, 45, 342-349. [CrossRef]

21. Kasman, A.; Duman, Y.S. $\mathrm{CO}_{2}$ emissions, economic growth, energy consumption, trade and urbanization in new EU member and candidate countries: A panel data analysis. Econ. Model. 2015, 44, 97-103. [CrossRef]

22. Pao, H.T.; Tsai, C.M. Modeling and forecasting the $\mathrm{CO}_{2}$ emissions, energy consumption, and economic growth in Brazil. Energy 2011, 36, 2450-2458. [CrossRef]

23. Saboori, B.; Sapri, M.; Bin Baba, M. Economic growth, energy consumption and $\mathrm{CO}_{2}$ emissions in OECD (Organization for Economic Co-operation and Development)'s transport sector: A fully modified bi-directional relationship approach. Energy 2014, 66, 150-161. [CrossRef]

24. Magazzino, $\mathrm{C}$. The relationship between real GDP, $\mathrm{CO}_{2}$ emissions, and energy use in the GCC countries: A time series approach. Cogent Econ. Financ. 2016, 4, 1152729. [CrossRef]

25. Magazzino, C. The Relationship among Real GDP, $\mathrm{CO}_{2}$ Emissions, and Energy Use in South Caucasus and Turkey. Int. J. Energy Econom. Policy 2016, 6, 672-683.

26. Magazzino, C. $\mathrm{CO}_{2}$ emissions, economic growth, and energy use in the Middle East countries: A panel VAR approach. Energy Source Part B Econ. Plan. Policy 2016, 11, 960-968. [CrossRef]

27. Magazzino, C. Economic Growth, $\mathrm{CO}_{2}$ Emissions and Energy Use in the South Caucasus and Turkey: A PVAR analyses. Int. Energy J. 2017, 16, 153-162.

28. Magazzino, $\mathrm{C}$. The relationship among economic growth, $\mathrm{CO}_{2}$ emissions, and energy use in the APEC countries: A panel VAR approach. Environ. Syst. Decis. 2017. [CrossRef] 
29. Fei, L.; Dong, S.; Xue, L.; Liang, Q.; Yang, W. Energy consumption-economic growth relationship and carbon dioxide emissions in China. Energy Policy 2011, 39, 568-574. [CrossRef]

30. Wang, S.S.; Zhou, D.Q.; Zhou, P.; Wang, Q.W. $\mathrm{CO}_{2}$ emissions, energy consumption and economic growth in China: A panel data analysis. Energy Policy 2011, 39, 4870-4875. [CrossRef]

31. Wang, S.; Li, Q.; Fang, C.; Zhou, C. The relationship between economic growth, energy consumption, and $\mathrm{CO}_{2}$ emissions: Empirical evidence from China. Sci. Total Environ. 2016, 542, 360-371. [CrossRef] [PubMed]

32. Zhang, X.P.; Cheng, X.M. Energy consumption, carbon emissions, and economic growth in China. Ecol. Econ. 2009, 68, 2706-2712. [CrossRef]

33. Chang, C.C. A multivariate causality test of carbon dioxide emissions, energy consumption and economic growth in China. Appl. Energy 2010, 87, 3533-3537. [CrossRef]

34. Long, X.; Naminse, E.Y.; Du, J.; Zhuang, J. Nonrenewable energy, renewable energy, carbon dioxide emissions and economic growth in China from 1952 to 2012. Renew. Sustain. Energy Rev. 2015, 52, 680-688. [CrossRef]

35. Xu, S.C.; He, Z.X.; Long, R.Y. Factors that influence carbon emissions due to energy consumption in China: Decomposition analysis using LMDI. Appl. Energy 2014, 127, 182-193. [CrossRef]

36. Zhang, L.; Gao, J. Exploring the effects of international tourism on China's economic growth, energy consumption and environmental pollution: Evidence from a regional panel analysis. Renew. Sustain. Energy Rev. 2016, 53, 225-234. [CrossRef]

37. Wang, S.; Fang, C.; Guan, X.; Pang, B.; Ma, H. Urbanisation, energy consumption, and carbon dioxide emissions in China: A panel data analysis of China's provinces. Appl. Energy 2014, 136, 738-749. [CrossRef]

38. Dickey, D.A.; Fuller, W.A. Distribution of the estimators for autoregressive time series with a unit root. J. Am. Stat. Assoc. 1979, 74, 427-431. [CrossRef]

39. Elliott, G.; Rothenberg, T.J.; Stock, J.H. Efficient Tests for an Autoregressive Unit Root. Available online: http:/ / www.nber.org/papers/t0130 (accessed on 18 April 2017).

40. Kwiatkowski, D.; Phillips, P.C.B.; Schmidt, P.; Shin, Y. Testing the null hypothesis of stationarity against the alternative of a unit root: How sure are we that economic time series have a unit root? J. Econ. 1992, 54, 159-178. [CrossRef]

41. Phillips, P.C.B.; Perron, P. Testing for a Unit Root in Time Series Regression. Biometrika 1988, 75, $335-346$. [CrossRef]

42. Zivot, E.; Andrews, D.W.K. Further evidence on the great crash, the oil-price shock, and the unit-root hypothesis. J. Bus. Econ. Stat. 2002, 20, 25-44. [CrossRef]

43. Johansen, S. Statistical Analysis of Cointegrated Vectors. J. Econ. Dyn. Control. 1988, 12, 231-254. [CrossRef]

44. Granger, C.W.J. Investigating causal relations by econometric models and cross-spectral methods. Econom. J. Econom. Soc. 1969, 37, 424-438. [CrossRef]

45. Granger, C.W.J. Testing for causality: A personal viewpoint. J. Econ. Dyn. Control 1980, 2, 329-352. [CrossRef]

46. Granger, C.W.J. Some recent development in a concept of causality. J. Econm. 1988, 39, 199-211. [CrossRef]

47. Engle, R.F.; Granger, C.W.J. Co-integration and error correction: Representation, estimation, and testing. Econom. J. Econom. Soc. 1987, 55, 251-276.

48. Granger, C.W.J. Causality, cointegration, and control. J. Econ. Dyn. Control 1988, 12, 551-559. [CrossRef]

49. Belloumi, M. Energy consumption and GDP in Tunisia: Cointegration and causality analysis. Energy Policy 2009, 37, 2745-2753. [CrossRef]

50. Mozumder, P.; Marathe, A. Causality relationship between electricity consumption and GDP in Bangladesh. Energy Policy 2007, 35, 395-402. [CrossRef]

(C) 2017 by the authors. Licensee MDPI, Basel, Switzerland. This article is an open access article distributed under the terms and conditions of the Creative Commons Attribution (CC BY) license (http://creativecommons.org/licenses/by/4.0/). 